\section{Honnør til Haukeland}

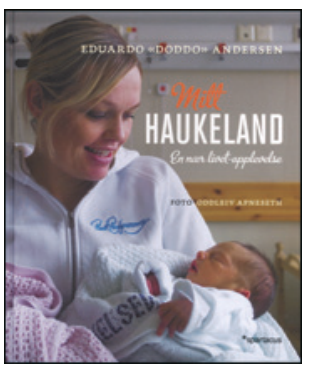

Eduardo «Doddo» Andersen

\section{Mitt Haukeland}

En nær livet-opplevelse. 244 s, ill. Bergen: Spartacus, 2012. Pris NOK 399

ISBN 978-82-430-0626-3

Det som nå heter Haukeland universitetssykehus i Bergen, ble opprettet i 1912. Hundreårsjubileet i 2012 ble blant annet feiret ved at journalisten, forfatteren og musikeren Eduardo «Doddo» Andersen og fotografen Oddleiv Apneseth fikk i oppdrag å skildre sykehuset, slik dets indre liv fremstår for utenforstående. Denne boken er resultatet.

Teksten består av 20 korte, poengterte kapitler, der forfatter og fotograf er innom ulike avdelinger og aktiviteter ved sykehuset. Miljøer fra prematuravdelingen til patologisk avdeling har fått visitt. Forfatteren beskriver det han ser i et lekent og til tider underfundig språk. Små faktabokser i margen supplerer bra.

Fotografiene teller her like mye som teksten. Å fotografere en helseinstitusjon er ikke lett, det vet alle som har prøvd. Når det er selve miljøet som er temaet, må bildene finne en middelvei mellom det konkrete og det abstrakte. Den som skildrer en stemning, må dessuten vokte seg for det banale. På et sykehus er det for øvrig ofte ikke alt som bør avbildes, og det kan være personvernhensyn som må ivaretas. Fototeknisk er et sykehus alltid vanskelig for den som ønsker å fotografere i farger, fordi det er så mange slags lys, fra grelle lysrør til gamle glødelamper og solstråler fra vinduet. Øyet og hjernen prosesserer fargeforskjellene automatisk for betrakteren, slik at vi ikke legger ikke merke til dem når vi ferdes rundt $i$ sykehuset. Men kameraet registrerer dem, ofte med et forvirrende resultat. Alt dette behersker fotograf Apneseth elegant. Både komposisjon og budskap er gjennomtenkt og konsekvent hele veien. Dessuten et ekstra pluss: Fotograf og forfatter har vært nøye med at alle de avbildede personene er nevnt ved navn. Det gir hele konseptet en større nærhet.

Et minus er layouten. Noen blanke, oransje helsider er lagt inn for å skille kapitlene. Det burde vært bilder isteden.

I denne velskrevne boken vil leseren uvegerlig hygge seg gjennom krinkelkrokene i labyrinten Haukeland, men det er alvor i hver krok. Det den utenforstående først og fremst sitter igjen med, er en forståelse, som for enkelte kanskje både er ny og overraskende, av hvor komplisert et stort universitetssykehus egentlig er, og en forståelse av at sykdomsbehandling er så mye mer enn det man umiddelbart tror. Det er så mange skjulte funksjoner som trår til hvis noe skulle gå galt. Det er samlet så mye bred kompetanse at de fleste eventualiteter kan møtes, nesten uansett hva som måtte skje. Her produseres dessuten medisinsk kunnskap.

La oss håpe at mange leser denne boken. Den er en motvekt mot oppslagene fra de tabloide og krisemaksimerende mediene som ser det som sitt samfunnsoppdrag å klage på ventelister og å lete opp mulig feilbehandling. Høyttalende politikere som har helse som merkesak, er heller ikke så mye å høre på, fordi det mange ganger mer er dem selv og deres parti saken gjelder, enn den helsetjenesten de beklager seg over. Mitt Haukeland hjelper velgerne slik at de lettere kan gjennomskue dem. Boken bør gi ettertanke hos dem som sverger til private tilbud. Hvordan er privatklinikkens annen eller tredje linje? De som heller mot det komplementære, bør lese side 207 om han som ble lam etter kiropraktorbehandling.

Kort sagt: Honnør til Haukeland!

\section{Et liv i kjærlighet}

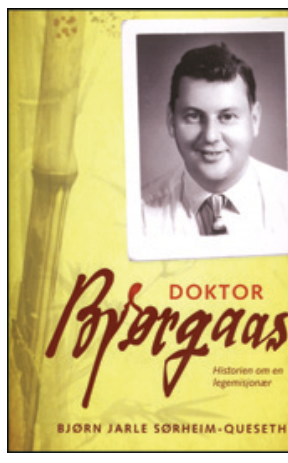

Bjørn Jarle Sørheim-Queseth
Doktor Bjørgaas

Historien om en legemisjonær. 318 s, ill. Kjeller: Hermon Forlag, 2012. Pris NOK 298 ISBN 978-82-302-10093

Dette er en bok for alle. Det er en fortelling om en norsk lege som ga sitt liv for de utstøtte og fattige, med et inderlig ønske om å hjelpe andre. Boken er lettlest, med et enkelt språk. Bilder og illustrasjoner viser Bjørgaas' liv i den enkelte periode.

Det er tre deler. Den første delen handler om Olav Bjørgaas' liv i den fattige delen av Stavanger. Olav ble født i 1926. Etter børskrakket på Wall Street i 1929 mistet faren til Olav jobben, og familien ble regnet som fattig. Foreldrene var fast bestemt på at barna måtte få en utdanning, og Olav jobbet hardt på skolen for å glede sine foreldre. I tillegg var han aktiv i søndagsskole og gutteklubb, hvor han hadde sitt første møte med misjonærer. Dette inspirerte Olav, og han fikk en magefølelse av at det var misjonær han skulle bli. I april 1946 dro Olav til Holland for å studere medisin. Der traff han Kari, som etter hvert ble hans livsledsager. De giftet seg i 1954, og fem dager etter bryllupet steg de om bord på $S / S$ Venos på sin første misjonsreise.

Andre del omhandler Olav og Karis liv som misjonærer på Taiwan. Olavs største interesse var spedalske, og på sin første arbeidsplass fikk Olav utdelt gummihansker, munnbind og vernestøvler som arbeidsuniform. De arvet etter hvert en klinikk på Taiwan, med to hjelpepleiere, en forretningsfører og en visjon om et fremtidig sykehus, som viste seg å bli en realitet. I tillegg startet Olav med fjernadopsjon, for å få penger til barn med tuberkulose.

I tredje og siste del reiser Olav ut for misjonsalliansen, som han har vært ansatt i hele tiden, for å kartlegge behov flere steder i verden. Kari var da hjemme i Norge med barna. 10. desember 2008 fikk Olav Bjørgaas Kongens fortjenstmedalje for sin innsats. Samme år utløp hans legelisens, og han valgte da å trekke seg tilbake, 82 år gammel.

Denne boken vil jeg anbefale til alle. Den er inspirerende, og for dem som ønsker å reise ut for å jobbe som misjonær, er det en perfekt start på turen.

\section{Linda Tånevik}

Kristiansand

Oppgitte interessekonflikter: Anmelder jobber selv som legemisjonær i Mosambik, Afrika. 